This is a peer-reviewed, accepted author manuscript of the following research article: McCormack, D., \& Shildrick, M. (2021). Transplantation: changing biotechnologies and imaginaries. Medical Humanities, 47(4), 385-

387. https://doi.org/10.1136/medhum-2021-012348

\title{
Transplantation: Changing Biotechnologies and Imaginaries
}

Donna McCormack and Margrit Shildrick

This Special Issue explores developing understandings of the limits and possible extensions of organ and tissue transplantation. Encompassing interdisciplinary research around biomedicine, philosophy, literature and film, Science and Technology Studies, anthropology, and Transplant Studies, the SI demonstrates how our understanding of embodiment is being transformed in the age of advanced biotechnologies. As the centuries-old project of the European Enlightenment is reaching inadequacy, what is urgently needed is a thorough reconfiguration of the bioethics, epistemology and ontology of what has hitherto been understood as normative human embodiment. In our own era, these parameters are already highly contested, and it is necessary to think different presents and futures that do not take for granted the wholeness, separation and independence of the normatively healthy human body. As a discourse of immense power in shaping social expectations, mores and practices, biomedicine is a prime site for generating critical rethinking, and we aim to elucidate the impact of specific biotechnologies on how we comprehend the transformative possibilities of varying human embodiment.

Our attention is focused on the uncertainty of the body with the specific aim of giving voice to developing understandings of the inter-/intra-corporeal embodiment that transplantation entails. The contributions to this SI work across a number of urgent issues and take on a wider range of corporeal entanglements than the analysis of 
transplantation usually entails. The transplanted materials themselves may be solid organs such as human hearts or wombs (Guntram), tissues such as faces (Lafrance), or porcine xenotransplants (Haddow). Such articles explore the recipient experience, whilst others address the issue of the deceased donor (Shildrick). Some are empirically-based, others more concerned with teasing out a theoretical framework (McCormack; Shildrick). And all touch on the bioethics of the procedures. What is at stake is the assumed purity - or at least clarity - of human embodiment and that our bodies and selves be acknowledged as assemblages of disparate and often inter-/intra-related parts. In short, the project of rethinking the socio-cultural imaginary in the context of transplantation offers a transformatory response to otherness and difference that can go beyond the dominant conventions of biomedicine to facilitate understandings of embodiment as intrinsically multiple, hybrid, and inter-/intra-dependent (Luciana \& Chen 2015; Hird \& Giffney 2008). Moreover, in reconfiguring the ontological and epistemological bases, it becomes apparent that what is required is a differently composed and intrinsically flexible bioethics. Each article offers expanded dimensions to Transplant Studies, whether through the lens of a relatively new procedure, such as faecal transplantation (Houf), or through an exploration of how temporality is central to embodiment (Wasson). This SI offers a critical approach by opening up the conversation on biotechnologies to issues of time, space and difference, as well as to changing imaginaries of the human and its relationality with non-human, technological and non-living others.

A related starting point for contributors is the need to reimagine how we approach transplantation, offering insights regarding the technology's ongoing development, as well as how it comes to be imagined by publics and cultural texts. Over the last fifty 
years the capacity for, and biomedical success of, solid organ transplantation and tissue grafts has risen dramatically with enhanced prospects of survival and recovery. At the very same time, however, there is a mismatch in public attitudes to transplantation. On the one hand, the seemingly beneficent nature of organ donation and transplantation is broadly supported as a welcome medical advance, and yet, on the other, the same procedures appear to provoke individual and socio-cultural anxiety (Haddow 2021). Not surprisingly, this response varies according to the nature of the organ or tissue itself with the longstanding ambivalence about heart or corneal transplants related to the status of hearts and eyes as supposedly expressive of a donor's essence. Similarly, the more recent occurrence of face grafts has aroused strong feelings of uncertainty and at times disgust, as does one of the latest additions to the list of possibilities, that of faecal transplantation. The transplant process is generally represented as an unproblematised and fully therapeutic social good, but the socio-cultural and personal responses indicate that something far more complex and ambivalent is at stake (Wasson 2020). Studies show that it is not the biomedical risk of transplantation that causes concern, but the manner in which the procedures pose irresolvable difficulties, not least around the question of identity and self and other relationality (Haddow 2005). This observation holds true both for older, more familiar forms of transplantation such as livers or hearts and for the emerging fields that concern the gut or the reproductive system.

All forms of transplantation can deeply disrupt the socio-cultural imaginary of what it means to be an embodied individual (Waldby 2002; Poole, Shildrick et al 2009), as well as what relationality means when one may feel physically and psychically connected to a living or deceased donor (McCormack 2015b). While transplant 
teams insist on anonymity between donor (or donor family) and recipient, personal narratives and fictional representations engage with the profound connection that ties the donor to the recipient, including - and often especially - in the case of deceased donation (McCormack 2021). Transplantation disrupts any easy definition of death (Lock 2002) and thereby raises socio-cultural issues around not only the moment of death, but what life, death and relationality mean when organs from a (sometimes deceased) donor give vitality to another human. Margrit Shildrick argues for an undoing of the binary of life and death, through a queering of the very terms. Specifically engaging with Deleuzian philosophy, her piece offers new ways for thinking life and death, particularly in the context of microchimerism and epigenetics. Where Shildrick engages with the imaginaries that transplantation is structured through and produces, Lisa Guntram addresses an emerging procedure in which the creation of new life is the defining rationale, namely uterine transplantation. Guntram's article explores interviews with women who were considering or had undergone a womb transplant, examining the ethical implications of such women needing to find their own donors. The utility of the transplanted uterus as a shortterm reproductive goal requires analysis, particularly of how transplantation itself becomes a normative procedure demanding a disciplining of human behaviour.

Where any mechanical prostheses may create a disturbance to the experience of embodiment, organic transplants - as forms of visceral prostheses (Shildrick 2022) produce a more acute break in the sense of an enduring self. Emerging empirical research reveals that recipients commonly experience highly troubling disruptions to their phenomenological wellbeing which indicates that high rates of clinically measured recovery are not matched by a sense of personal flourishing (Ross et al 
2010, Shaw 2010). In the context of western adherence to the founding binary of self and other, transplantation breaks down the boundaries of normative embodiment and identity, such that whenever the donor organ crosses the threshold of the recipient body, it may invoke ontological and epistemological questions of self and other, life and death, and normative temporality. This is not an abstract concern insofar as the transplanted organ brings to its new site so-called alien DNA that will persist for life (Martin 2010, Shildrick et al 2009) and that will circulate throughout the peripheral blood supply (Shildrick 2015). Indeed, the fundamental question of 'who am I?' may become unanswerable for some organ recipients. Marc Lafrance's article speaks to this concern through a critical analysis of media material on a face transplant. That the face is tied fundamentally to identity and is deemed to define personhood is central to his exploration of media reports on the relative public ease with which one recipient accepts a transplanted face. Lafrance shows the destructive impact of immunosuppression on embodiment and addresses questions of justice in accessing health care and pharmaceutics, particularly in countries where health systems require payment. Where the human face may perturb both the sense of individual identity and how donor families understand the ongoing presence of their family member, the disruption to notions of the sovereign self becomes all the more acute when the graft is not simply human, but involves the innumerable forms of microbial life that inhabit the gut in which a majority of those organisms carry strictly non-human DNA. Jessica Houf addresses this issue exploring the relationality between microbial beings and the humans who choose faecal transplantation. Her article challenges traditional notions of bodily integrity and offers new reflections on the centrality of the non-human to selfhood and wellbeing. Where Houf explores the operation of disgust associated with faecal transplantation, Gill Haddow addresses 
the feelings of abjection aroused by innovations in porcine organ transplantation. Undertaking empirical research that asks whether humans prefer pig, technological or human organs, Haddow takes us into the realm where clinical preferences and public desires do not clearly meet. Instead, she examines the fears around becoming non-human or less-than-human when taking in technological or animal parts.

Along with immediate empirical consequences, the event of transplantation may also exceed the temporality of the biomedical procedure in at least two respects. First it may radically change the constitution of the body by incorporating material that figures a different genetic past and future. Second, it introduces interlinked questions of belonging often in the forms of foreignness, intrusion and belonging (McCormack 2012); the relation between host and guest and thus the meaning of hospitality (Shildrick 2013; McCormack 2016); and always the matter of race, sex and gender (McCormack 15a). The embodied self is never neutral. Sara Wasson's article grapples with the temporality of transplantation, revealing how transplant narratives do not follow a curative time of diagnosis-treatment-cure, but instead convey a temporality of disruption and waiting. Her article examines how Gothic modes emerge in the narration of transplantation and offer radically different experiences of transplantation from those narrated by clinicians. Representations in literature and film show acutely this sense that life and death are not distinct categories and that time does not flow neatly from birth and healthiness through to illness and death. On the contrary, transplantation foregrounds a haunting temporality that suggests death may constitute life. Furthermore, literature and film portray this crossing of the bodily boundary as a condensed site of anxieties around the traversing of other borders. In these instances, transplantation becomes a way of figuring contemporary issues 
around migration, violence towards purported difference and how we may imagine a mode of being with others that does not repeat the historical traumas of colonialism (McCormack 2016). Indeed, transplantation opens up an imaginary of the body politic both to reveal past and ongoing violence and to uncover new ways of being with others. Donna McCormack's article tackles these issues through a focus on Indigenous and queercrip temporalities and spatialities in Larissa Lai's The Tiger Flu, exploring how histories of colonialism and ongoing neo-colonialism are mapped onto the fantastical donor body of the humanoid, but not human, 'starfish'. Exploring the body politic through the lens of transplantation, McCormack examines the link between the restoration of the normative body as an unchanged container and the imagined resumption of linear temporality. The queercrip times and spaces create a spatio-temporal imaginary that is anti-racist, bears witness to historical and ongoing genocides, and opens up the possibility of futures for those deemed disposable.

Transplantation is tied to global injustice, as McCormack discusses. Yet few of these existential questions and socio-political issues are acknowledged within biomedical science or by media narratives that promote the good of transplantation. There is an unaddressed problem that indicates how conventional western bioethics is ill-suited to analyse problems thrown up by rapidly expanding technologies. Tellingly, the context explored Rhonda Shaw and Robert Webb - who compare Eurocentric and Māori understandings of transplantation - shows very clearly that disturbances to the sense of self and the limits of bioethics outlined in some of the articles are closely related to their western contexts. Similarly, Shildrick's research points to a very different donor family experience in a First Nations context compared to that of settler Canadians, while McCormack's article explores how Indigenous theories shift 
focus to land claims, racial injustice and ongoing colonial violence in transplantation. Such intersectional approaches yield many questions that have yet to be more widely explored. This focus on indigeneity is a small step in challenging our own methodologies to draw out whose lives are saved, at what cost, and how may we imagine safe presents and futures that do not repeat the violence of colonialism.

With its diverse methodologies and analyses, this SI engages with urgent questions concerning the meaning of life and death, justice, temporality and spatiality, and listening to those who may not always fit within dominant narratives of transplantation. It scrutinises the non/a/in/human in organ transplantation, and their representations, and opens up the present to a myriad of bodily configurations.

Haddow, Gill. 2021. Embodiment and Everyday Cyborgs: Technologies that alter subjectivity. Manchester: Manchester University Press.

_- 2000.) The phenomenology of death, embodiment and organ transplantation. Sociology of Health \& Illness. 27(1): 92-113.

Giffney, Noreen, and Myra J. Hird. 2008. Introduction: Queering the Non/Human. In Queering the Non/Human, edited by J. Hird Myra and Noreen Giffney. London: Routledge.

Lai, Larissa. 2018. The Tiger Flu: A Novel. Vancouver: Arsenal Pulp Press. Lock, Margaret (2002) Twice Dead: Organ Transplants and the Reinvention of Death. Berkeley, CA: University of California Press. 
Luciana, Dana \& Chen, Mel Y. 2015. Has the Queer Ever Been Human? GLQ: $A$ Journal of Lesbian and Gay Studies. 21(2-3): 182-207.

Martin, Aryn .2010. Microchimerism in the Mother(land): blurring the borders of body and nation. Body \& Society 16(3): 23-50.

McCormack, Donna. 2021. The Haunting Temporalities of Transplantation. Body \& Society 27(2): 58-82.

__ 2016. Living with others inside the self: decolonising transplantation, selfhood and the body politic in Nalo Hopkinson's Brown Girl in the Ring. Medical Humanities. 42(2): 252-258.

—. 2015a. The Transplant Imaginary and Its Postcolonial Hauntings. In Bodily Exchanges, Bioethics and Border Crossing: Perspectives on Giving, Selling and Sharing Bodies. edited by Erik Malmqvist and Kristin Zeiler, 135-52. London: Routledge.

_. 2015b. Transplant Temporalities and Deadly Reproductive Futurity in Alejandro González Iñárritu's 21 Grams. European Journal of Cultural Studies 19 (1): $51-68$.

_ 2012. Intimate Borders: The Ethics of Human Organ Transplantation in Contemporary Film. The Review of Education, Pedagogy and Cultural Studies. 34(3-4): 170-83.

Poole, Jen, Margrit Shildrick, Patricia McKeever, Susan Abbey and Heather Ross. 2009. 'You might not feel like yourself': heart transplants, identity and ethics. in S. 
Murray and D. Holmes (eds) Critical Interventions in the Ethics of Healthcare:

Challenging the Principle of Autonomy in Bioethics. London: Ashgate: 33-44.

Ross, Heather, Susan Abbey, Enza de Luca, Oliver Mauthner, Patricia McKeever, Margrit Shildrick, and Jen Poole. 2010. What They Say versus What We See:

'Hidden' Distress and Impaired Quality of Life in Heart Transplant Recipients. J. of Heart and Lung Transplantation. 29(10): 1142-1149.

Shaw, Rhonda. 2010. Organ Donation in Aotearoa/New Zealand: Cultural Phenomenology and Moral Humility. Body \& Society. 16(3): 127-147.

Shildrick, Margrit. 2022 forthcoming. Visceral Prostheses: Somatechnics and Posthuman Embodiment. London: Bloomsbury.

Shildrick, Margrit. 2015. Chimerism and immunitas: the emergence of a posthumanist biophilosophy. In Resisting Biopolitics: Philosophical, Political and Performative Strategies. eds. S. Wilmer and A. Zukauskaite. London: Routledge: 95109.

Shildrick, Margrit. 2013. Hospitality and 'the gift of life': reconfiguring the other in heart transplantation. in Embodied Selves. ed. Kathleen Lennon. Basingstoke: Palgrave Macmillan: 196-208.

Shildrick, Margrit, Patricia McKeever, Susan Abbey, Jen Poole and Heather Ross. 2009. Troubling Dimensions of Heart Transplantation. Medical Humanities. 35 (1).

Waldby, Catherine. 2002. Biomedicine, tissue transfer and intercorporeality. Feminist Review. 3(3): 239-254.

Wasson, Sara. 2020. Transplantation Gothic: Tissue Transfer in Literature, Film and Medicine. Manchester: Manchester University Press. 